Tomasz Duraj (D) https://orcid.org/0000-0003-1561-5916

University of Łódź

\title{
PARADIGM OF SUBORDINATE WORK VERSUS REMOTE WORK
}

\begin{abstract}
The paradigm of subordinate work already emerged in the early stages of the development of labour law and is still functioning to this day, which is widely accepted both in labour law doctrine and in judicial practice. The author assesses the timeliness of the traditional paradigm of subordinate work in conditions of development of new technologies and the spread of modern forms of work provision, doing so on the example of remote work. According to the author, despite working outside the workplace, while retaining much greater autonomy, in addition to the constant supervision of the employer, the remote worker is still subject to a multifaceted dependence on the employer. This means that the paradigm of subordinate work continues to apply and is strongly present also in atypical forms of work.
\end{abstract}

Słowa kluczowe: paradygmat pracy podporządkowanej, praca zdalna, podporządkowanie, uprawnienia kierownicze, nietypowe stosunki zatrudnienia

Keywords: paradigm of subordinate work, remote work, subordination, managerial powers, atypical employment relationships

ASJC: 3308, JEL: K31

\section{The paradigm of subordinate work}

The paradigm of subordinate work already emerged in the early stages of the development of labour law, which at that time consisted primarily of factory workers working in a cooperative and team manner (Gersdorf 1993, p. 53; Skąpski 2003, p. 149). This paradigm is still functioning to this day, which is widely accepted both in labour law doctrine and in judicial practice. De lege lata under Polish labour law sources of the paradigm of subordinate work should be seen primarily in two provisions of the Labour Code Act of 26 June 1974 (Dz.U. 2020, item 1320 consolidated text, as amended, hereinafter referred to as: the Labour Code, l.c.).

First, in Art. 22(1) 1.c., according to which, by entering into an employment relationship, the employee undertakes to perform work of a specified type for the benefit 
of an employer and under his supervision, in a place and at the time specified by the employer. At the same time, the employer undertakes to employ the employee in return for remuneration. Secondly, in Art. 100(1) 1.c., where the legislature requires the employee to follow the instructions of his superiors concerning work if they do not conflict with the law or the employment contract.

Employee subordination in the literature of the subject (see, e.g., Salwa, Szubert, Święcicki 1957, pp. 52-53, 75-76; Szubert 1972, pp. 86-87; Mroczkowski 1976, pp. 16, 58 ff; Szurgacz 1995, p. 151; Lewandowski, Góral 1996, p. 29; Rączka 1996, p. 50; Piątkowski 2000, pp. 34 ff; Kubot 2002, p. 233; Duraj 2015, pp. 159 ff; Duraj 2017, pp. $61 \mathrm{ff}$ ) and judicature (see, e.g., judgment of the Supreme Court of 27 October 1927, I C 515/26, Zb.Urz. 1927, No. 126; judgment of the Supreme Court of 4 April 1930, C 201/30, Zb.Urz. 1930, No. 84; judgment of the Supreme Court of 18 December 1931, I C 705/31, Zb.Urz. 1931, No. 244; judgment of the Supreme Court of 19 April 1932, C 2105/31, Zb.Urz. 1932, No 86; judgment of the Supreme Court of 20 March 1965, III PU 28/64, OSPiKA 1965, No. 12, item 253; judgment of the Supreme Court of 22 January 1970, II PR 298/69, not published; judgment of the Supreme Court of 2 December 1975, I PRN 42/75, "Służba Pracownicza" 1976, No. 2; judgment of the Supreme Court of 7 October 1980, IV PRN 8/80, PiZS 1982, No. 6; judgment of the Supreme Court of 11 September 1997, II UKN 232/97, OSNP 1998, No. 13, item 407; judgment of the Supreme Court of 4 December 1997, I PKN 394/97, OSN 1998, No. 20, item 595; judgment of the Supreme Court of 28 January 1998, II UKN 479/97, OSNP 1999, No. 1, item 34; judgment of the Supreme Court of 3 June 1998, I PKN 170/98, OSN 1999, No. 11, item 369; judgment of the Supreme Court of 4 December 1998, I PKN 484/98, OSNP 2000, No. 2, item 62; judgment of the Supreme Court of 15 October 1999, I PKN 307/99, OSNP 2001, No. 7, item 214; judgment of the Supreme Court of 5 December 2000, I PKN 127/00, OSNP 2002, No. 15, item 356) is generally regarded as the most important structural feature of an employment relationship, a necessary element of it, determining the identity of that relationship and distinguishing it from other legal employment relationships, in particular civil law relationships. For the purposes of this study, it must be assumed that subordination on the basis of an employment relationship is a relationship of dependency between an employee and an employer, in which the employer has certain managerial powers enabling him to: organise the work process and to specify, by binding instructions, the employee's obligations in relation to the subject matter of the work (type of work and the way in which it is carried out) and the time and place of work (see, more broadly, Duraj 2013, pp. 74 ff).

\section{Remote work in the Polish legal system}

Polish legal system saw the emergence of remote work at the outbreak of the coronavirus pandemic as a means of combating COVID-19. In accordance with Art. 3 of the Act of 2 March 2020 on special solutions related to the prevention, counteraction and 
combating of COVID-19, other infectious diseases and crisis situations caused by them (Dz.U. 2020, item 374 as amended), in order to counteract COVID-19, the employer may instruct the employee to carry out, for a limited period of time, the work specified in the employment contract, outside the place of its permanent performance (Pisarczyk, Boguska 2020, pp. $8 \mathrm{ff}$ ). The current regulation of remote work is extraordinary and temporary, since the legislature has assumed that it is to apply in Poland during the period of epidemic emergency or epidemic declared due to COVID-19 and 3 months after their cancellation. While in the original version of the legislation the application of this unusual form of work was not subject to any restrictions, under the Anti-Crisis Shield 4.0 (Dz.U. 2020, item 1086), the legislature clarified both the scope and conditions for the use of remote work and the reciprocal rights and obligations of the parties to the employment relationship in connection with the order to carry out that work. Importantly, the possibility of using remote work has been limited, making it dependent on the type of work that must allow the employee to perform certain activities outside the workplace. Furthermore, the legislation clearly indicates that remote work may in particular be carried out by means of direct distance communication (e.g., IT sector, programming, graphics and design, website positioning, translation, copywriting) or relate to the performance of manufacturing parts or material services. The explanatory memorandum states that "this calculation is open and thus does not limit the type of remote work allowed or the means by which this work can be carried out." It is clear that certain categories of activities cannot be carried out at a distance, as they require to be present in an employer's workplace (e.g., jobs related to construction, agriculture or transport).

Pursuant to Art. 3(4) of the COVID-19 Act, the (Dz.U. 2020, item 1842 consolidated text) employer is obliged to provide the employee with the tools and materials needed to perform remote work and logistical services in this regard (Książek, Witoszko 2020, point 4). In addition, the use of tools or materials belonging to the employee himself has been permitted, provided that this makes it possible to respect and protect confidential information and other legally protected secrets, including trade secrets or personal data, as well as information the disclosure of which could put the employer at risk of loss or damage (point 5).

\section{Subordination of the employer's employee in the process of remote work}

When analysing the paradigm of subordinate work from the perspective of atypical forms of employment, two fundamental positions can be observed in the doctrine of labour law. According to the first, the progressive technological development, the introduction of modern varieties of work organisation and new, atypical (flexible) forms of employment lead to a gradual shift away from the paradigm of subordinate work. In this case, the need for the employee's narrow specialization, personal skills, vast 
knowledge and experience in a particular field, as well as his creativity and autonomy, disqualify the employee's subordination to the employer in the traditional sense of the term (Świątkowski 2011, p. 55). According to the second position, it cannot be assumed that the traditional paradigm of subordinate labour is completely obsolete in the new conditions of civilisation, as adapted only to highly hierarchical organisational structures. According to Tadeusz Zieliński, a complete departure from the principle of subordination cannot be taken into account, not least because an employer who bears the risks associated with the work process and the activity of employees in favour of them cannot be deprived of any influence on their conduct (Zieliński 1999, pp. 11-12). Being in favour of the second approach, I believe that, regardless of the nature of the work provided and the position held by the worker, the paradigm of subordinate work is still valid and does not prevent the autonomy and creativity of workers, nor does it jeopardise the development of new, flexible forms of work, as can be seen very well in the example of remote work. Even if the employee carries out his duties outside the workplace for a long time (e.g., at home), the core of his subordination to the employer is maintained, under which the employer has the power to specify, by binding instructions, the employee's obligations. He may not exercise these powers by guaranteeing a remote worker far-reaching autonomy and independence, but he still enjoys that competence. Instructions and orders issued by the employer during remote work can concern both the substance of the work provided (the employer can specify the tasks of the employee and the priority status as well as the way they need to be carried out) and the time necessary for their realization. Employer's instructions may also specify the less important, often secondary, obligations of the remote worker relating to the technical and organisational side of the work (Duraj 2013, pp. $73 \mathrm{ff}$ ).

The detailed regulations of remote work already presented above show a very wide range of powers of the employer over the employee. This can be clearly seen in the very design of the introduction of this form of work. Remote work de lege lata is outsourced to the employee by unilateral decision of the employer, who, in order to counteract COVID-19, has the right to direct him, during the period of the epidemic or epidemic emergency and within 3 months after their cancellation, to carry out, for a limited period of time, the work specified in the employment contract, outside the place of permanent performance, and the worker, in principle, may not refuse to do so (Art. 3(1) of the COVID-19 Act). The legislature merely generally defined the conditions for the possibility of the employer to ask his employees to work remotely, leaving the employer far-reaching freedom in that regard. In accordance with Art. 3(3) of the COVID-19 Act, the performance of that work may be recommended if the worker has the right skills, technical facilities and sufficient housing conditions to carry out such work and the type of work so allows. This means that the unilateral decision of the employer to introduce this form of work to counteract COVID-19 has been subject to three essential conditions. First of all, the type of work must allow the employee to perform certain activities outside the workplace. However, the legislator does not prejudge a priori what work can be carried out remotely. Secondly, the worker 
must have the skills to carry out such work, which, however, cannot be equated with the employee's substantive qualifications confirmed by a certain level of education-the worker must have such qualifications already at the stage of recruitment for the job in question, and this is a sine qua non condition for his employment in the workplace. Therefore, when it comes to having the skills to perform remote work, it is necessary to understand it as certain practical competences relating, for example, to the operation of computer equipment or internet applications enabling the employee to contact the hiring entity and its contractors. In this respect, it is the employer's responsibility to provide the employee with appropriate training and instruction. Thirdly, remote work may be recommended if the worker has the technology resources and sufficient housing conditions to perform such work. When it comes to technology resources, it is important to point out, first of all, the need to access a high-speed internet connection through which it will be possible to contact the employer and his contractors. In this respect, the employer is obliged to provide the employee with the tools and materials needed to perform the remote work and the necessary logistic support. As far as housing conditions are concerned, the employee should have the sufficient conditions that would enable him to comfortably carry out the tasks and activities entrusted. Remote work does not have to be done at the employee's home. There are no legal obstacles for him to perform this work in another place that meets all health and safety requirements. This is, in fact, the only condition which should be subject to the sole assessment of the worker, who may subjectively conclude that, despite having a large apartment, due to other circumstances (e.g., a large family), there are insufficient housing conditions to provide remote work. In such a situation, the employee has the right to refuse to comply with the employer's instructions regarding working from home, which cannot have any negative consequences for him and, in particular, cannot be the basis for the termination of his employment contract.

The fulfilment of the above mentioned three conditions allows the employer to introduce remote work unilaterally at virtually any time. It is for the employer to decide what tasks the employee will perform specifically outside the workplace (they must, of course, be compliant with the description of duties set out in the employment contract), for what period of time he will work remotely (the restriction here is an epidemic state) and with what frequency (whether permanently, ad hoc if necessary, or following the hybrid approach-mix of working from home and the office). In fact, the legislature, under Art. 3 of the COVID-19 Act, extended for the period of the pandemic the managerial powers of the employer to unilaterally change for a limited period the place of work specified in the employment contract. Moreover, the employer has unlimited possibilities to call off the remote work request. It can do this at any time, without giving a reason, which results in the employee being obliged to immediately appear in the workplace or other place designated to provide work in accordance with the employment contract. An unjustified refusal to perform a remote work order or to withdraw that work may entail both the ordinal or material liability of the worker as well as the loss of employment, including immediate termination of the employment contract. 
Regardless of whether remote work will be introduced, as de lege lata, by unilateral decision of the employer, or by agreement between the parties to the employment relationship (as proposed by the government's draft law, which seeks to permanently normalize this institution in the provisions of the Labour Code), during its implementation the employer, despite the distance, can still effectively exercise his managerial powers over employees who work outside the workplace. Firstly, he may constantly (in the course of the performance of the work) update the scope of the employee's duties by means of binding instructions, deciding on the type and priority status of the tasks carried out on the working day, the manner in which those activities are carried out, and the selection of the necessary methods and means by which they will be carried out. Of course, the form of issuing these directions changes and must include remote work specifics (communication by mail, phone call, texting, instant messaging, Microsoft Teams, Google Meet or Zoom applications).

Secondly, the employer may specify further the employee's obligations with regard to the organisation of the working time. In particular, this applies to: how often the job will be performed remotely (whether it is to be permanent or incidental), the days of its performance and the hourly dimension, the working time system (e.g., task-related working time), overtime, night work or Sunday and public holidays (see, more broadly, Książek, Witoszko 2020, points 1.16 and 1.17). Thirdly, it is up to the employer to decide, using what tools, means and materials remote work will be provided, which, of course, depends to some extent on the type of work and the specificity of its performance. Not only does the employer have the ability to interfere in the process of providing remote work in its own right, but also has a number of control powers which enable him to assess on an ongoing basis the regularity, diligence and conscientiousness of the performance of the duties entrusted to the employee and to verify the efficiency and effectiveness of the work he provides. In this respect, the employer may apply, on the terms and within the limits set out in Art. $22^{3}$ l.c., the monitoring of employees using modern ICT solutions. Current advanced development of ICT gives the employer the opportunity to use programs for monitoring the use of company computer (Internet or e-mail) by employees, work phone (wiretaps and billing) and devices for tracking their location by phone or GPS (Dörre-Nowak 2004, pp. 8 ff; Lach 2004, pp. 264 ff; Czechowski 2006, pp. $7 \mathrm{ff}$ ). In order to strengthen the effectiveness of the employer's supervisory powers, the Polish legislature grants the employer the right to keep records of the activities performed by the employee (Art. 3(6) of the COVID-19 Act). The employer may do so at any time by ordering the employee, by individual directions, to keep such records and at the same time indicating how detailed the record should be. In particular, this record should include a description of the activities carried out by the remote worker, as well as the date and time of their performance. In addition, the employer's instructions must specify the form and frequency of the records of the activities performed by the remote worker (Art. 3(7) of the COVID-19 Act). In the absence of a separate regulation, the employer should be able to apply, by analogy, Art. $67^{14}$ l.c., according to which the employer has the right to check the performance of work by a teleworker at the place of 
work. If the work is carried out at home of a remote worker, the employer may carry out an inspection regarding: 1) performance of the duties, 2) for the purpose of inventory, maintenance, service or repair of the entrusted equipment, as well as its installation, 3 ) with regard to health and safety at work. The condition for carrying out such an inspection shall be the prior written consent of the remote worker, either by electronic means of communication or similar means of individual distance communication. Of course, in the case of home inspections, the protective mechanisms set out in Art. $67^{14}(3)$ of the Labour Code shall apply. According to that provision, the employer must adapt the manner in which the checks are carried out to the place of work and the nature of that work, and the performance of the inspection activities must not affect the privacy of the remote worker and his family, nor hinder the use of the premises in a manner consistent with their intended purpose.

\section{Conclusions and comments de lege ferenda}

Whether remote work is introduced, as de lege lata, by an explicit direction of the employer or by an agreement between the parties to the employment relationship, as proposed by the government's draft law, the paradigm of subordinate work remains in force and is strongly present in this unusual form of work. As I have shown before, an employee, despite working outside the workplace, with much greater autonomy, in addition to the constant supervision of the employer, is still subject to a multifaceted dependence on the hiring entity. Of course, due to the specificity of remote work, there are some disadvantages in the exercise of the employer's managerial powers. The restrictions apply both to the ability to manage the work process on an ongoing basis and to respond quickly to changing circumstances and needs, as well as to decide on the organisation of work, and controlling the diligence and efficiency of the performance of tasks by a remote worker. Nevertheless, the current level of advancement of information technology guarantees the employer a sufficient level of power over employees working outside the workplace, which does not differ significantly from the typical employment relationship. Therefore, Tadeusz Zieliński's position claiming that it is impossible to completely eliminate the employer's supervisory powers and, on the other hand, the subordination of the employee in employment relations (Zieliński 1999, pp. 12-13) remains a valid point. In his view, moving away from the criterion of subordinated work in the context of an employment relationship would undermine the point of the further existence of labour law (Zieliński 2000, p. 57).

The government's proposal to introduce remote labour into the Labour Code and to unify this regulation with telework is completely unconvincing. The introduction of very detailed procedures and rules for the use of distance work will discourage employers from using this form of work, and the main advantage of the existing rules is flexibility in the use of remote work, where the employer can temporarily ask the employee to perform his duties remotely (e.g., from home) and cancel such request at any time, at 
his own discretion, will become pointless. I therefore believe that remote work should be regulated separately from teleworking and, importantly, only to a limited extent. The Polish legislature, in addition to the possibility of introducing remote work by agreement between the parties to the employment relationship, should, as in Art. 42(4) of the Labour Code, guarantee the employer the right to use that institution unilaterally in cases justified by the needs of the employer, for a period of not more than 60 days per calendar year, for example.

\section{References}

Czechowski P. (2006) Geolokalizacja pracownikow - nowe wyzwania dla prawa pracy?, "Praca i Zabezpieczenie Społeczne," nr 4.

Dörre-Nowak D. (2004) Monitoring w miejscu pracy a prawo do prywatności, "Praca i Zabezpieczenie Społeczne," nr 9.

Duraj T. (2013) Podporządkowanie pracowników zajmujących stanowiska kierownicze w organizacjach, Warszawa.

Duraj T. (2015) Ewolucja pracowniczego podporzadkowania jako cechy konstrukcyjnej stosunku pracy w świetle przepisów prawa pracy [in:] A. Kosut, W. Perdeus (red.), Przemiany prawa pracy. Od kodyfikacji do wspótczesności. Księga jubileuszowa dedykowana Profesor Teresie Liszcz, Lublin.

Duraj T. (2017) Granice pomiędzy stosunkiem pracy a stosunkiem cywilnoprawnym - głos w dyskusji, "Gdańsko-Łódzkie Roczniki Prawa Pracy i Prawa Socjalnego," nr 7.

Gersdorf M. (1993) Umowa o prace a umowa o dzieło i zlecenia, "Praca i Zabezpieczenie Społeczne," nr 9.

Książek D., Witoszko W. (2020) [in:] K.W. Baran (red.), Komentarz do niektórych przepisów ustawy o szczególnych rozwiąaniach związanych z zapobieganiem, przeciwdziałaniem i zwalczaniem COVID-19, innych chorób zakaźnych oraz wywołanych nimi sytuacji kryzysowych [in:] Tarcza antykryzysowa 1.0-4.0, ustawa o dodatku solidarnościowym i inne regulacje jako szczególne rozwiazania w prawie pracy, prawie urzędniczym i prawie ubezpieczeń społecznych zwiazane $z$ COVID-19. Komentarz, LEX.

Kubot Z. (2002) Pojęcie kierownictwa pracodawcy [in:] M. Matey, L. Nawacki, B. Wagner (red.), Prawo pracy a wyzwania XXI-go wieku. Ksiega Jubileuszowa Profesora Tadeusza Zielińskiego, Warszawa.

Lach A. (2004) Monitorowanie pracownika w miejscu pracy, "Monitor Prawa Pracy," nr 10.

Lewandowski H., Góral Z. (1996) Przeciwdziałanie stosowaniu umów cywilnoprawnych do zatrudnienia pracowniczego, "Praca i Zabezpieczenie Społeczne," nr 12.

Mroczkowski R. (1976) Instytucja podporzadkowania pracownika według polskiego kodeksu pracy, Zarys problematyki prawnej, Lublin.

Piątkowski J. (2000) Zagadnienia prawa stosunku pracy, Toruń.

Pisarczyk Ł., Boguska A. (2020) Sfera zatrudnienia w działaniach antykryzysowych. Wybrane zagadnienia, "Monitor Prawa Pracy," nr 5.

Rączka K. (1996) Stosunek pracy a cywilnoprawne umowy o świadczenie pracy, "Praca i Zabezpieczenie Społeczne," nr 11. 
Salwa Z., Szubert W., Święcicki M. (1957) Podstawowe problemy prawa pracy, Warszawa.

Skąpski M. (2003) Glosa do wyroku NSA z dnia 5 grudnia 2001 r., II SA 2091/01, OSP, No. 3, item 33 .

Szubert W. (1972) Zarys prawa pracy, Warszawa.

Szurgacz H. (1995) Charakter prawny zatrudnienia członków zarządu w spółce akcyjnej [in:] J. Frąckowiak (red.), Spółka jako podmiot gospodarczy, Wrocław.

Świątkowski A.M. (2011) Przedmiot stosunku pracy. Rozważania de lege lata $i$ de lege ferenda [in:] L. Florek, Ł. Pisarczyk (red.), Współczesne problemy prawa pracy i ubezpieczeń społecznych. XVIII Zjazd Katedr i Zakładów Prawa Pracy i Ubezpieczeń Społecznych, Warszawa, 26-28 maja 2011 r., Warszawa.

Zieliński T. (1999) Problem rekodyfikacji prawa pracy, "Państwo i Prawo," nr 7.

Zieliński T. (2000) Umowy o zatrudnienie w aspekcie rekodyfikacji prawa pracy [in:] Z. Kubot (red.), Szczególne formy zatrudnienia, Wrocław.

\section{Court sentences}

Judgment of the Supreme Court of 27 October 1927, I C 515/26, Zb.Urz. 1927, No. 126. Judgment of the Supreme Court of 4 April 1930, C 201/30, Zb.Urz. 1930, No. 84. Judgment of the Supreme Court of 18 December 1931, I C 705/31, Zb.Urz. 1931, No. 244. Judgment of the Supreme Court of 19 April 1932, C 2105/31, Zb.Urz. 1932, No 86.

Judgment of the Supreme Court of 20 March 1965, III PU 28/64, OSPiKA 1965, No. 12, item 253. Judgment of the Supreme Court of 22 January 1970, II PR 298/69, not published.

Judgment of the Supreme Court of 2 December 1975, I PRN 42/75, "Służba Pracownicza" 1976, No. 2.

Judgment of the Supreme Court of 7 October 1980, IV PRN 8/80, PiZS 1982, No. 6.

Judgment of the Supreme Court of 11 September 1997, II UKN 232/97, OSNP 1998, No. 13, item 407.

Judgment of the Supreme Court of 4 December 1997, I PKN 394/97, OSN 1998, No. 20, item 595. Judgment of the Supreme Court of 28 January 1998, II UKN 479/97, OSNP 1999, No. 1, item 34. Judgment of the Supreme Court of 3 June 1998, I PKN 170/98, OSN 1999, No. 11, item 369. Judgment of the Supreme Court of 4 December 1998, I PKN 484/98, OSNP 2000, No. 2, item 62. Judgment of the Supreme Court of 15 October 1999, I PKN 307/99, OSNP 2001, No. 7, item 214. Judgment of the Supreme Court of 5 December 2000, I PKN 127/00, OSNP 2002, No. 15, item 356.

\section{Legal acts}

The Labour Code Act of 26 June 1974, Dz.U. 2020, item 1320 consolidated text, as amended.

The Act of 2 March 2020 on special solutions associated with the prevention, counteracting and control of COVID-19, other infectious diseases and the crisis situations they cause, Dz.U. 2020, item 1842 consolidated text, as amended.

The Act of 19 June 2020 on interest subsidies for bank loans granted to entrepreneurs affected by COVID-19 and on simplified proceedings for approval of an arrangement in connection with the occurrence of COVID-19, Dz.U. 2020, item 1086. 